\title{
Reflection of the War in Afghanistan by Means of Alexander lelagin's Creativeness
}

\author{
Lebiedieva Nadiia ${ }^{1,2}$ \\ ${ }^{1}$ Department of Public Administration, Interregional Academy of Personnel Management, Kyiv, Ukraine \\ ${ }^{2}$ Department of Foreign Languages, Kherson State Agrarian University, Kherson, Ukraine
}

Email address:

vsesvit894@ukr.net

\section{To cite this article:}

Lebiedieva Nadiia. Reflection of the War in Afghanistan by Means of Alexander Ielagin's Creativeness. International Journal of Law and Society. Vol. 1, No. 1, 2018, pp. 1-9. doi: 10.11648/j.ijls.20180101.11

Received: October 30, 2017; Accepted: November 14, 2017; Published: December 23, 2017

\begin{abstract}
This article is dedicated to the poetry by a participant of war in Afghanistan, Ukrainian poet Alexander Ielagin. As it's widely known, poetry is the art of word. The most sacred of the human feelings are expressed by means of poetry. The main aim of the article is to describe the poetry features of a war actions' participant, the contemporary Ukrainian poet Alexander Ielagin and to acquaint English-speaking colleagues with military-patriotic creativeness in Ukraine. The object of this research is the formation of an unified system of knowledge about the poetry of A. Ielagin in the field of spiritual enlightenment. The subject of scientific research, that are verses, poetic texts of songs, and their typological links with historical and philosophical thought. It is concluded that Afghanistan served as the impetus for creativeness, which determined the further development of Alexander Ielagin's talent. Returning home, he begins to write verses that "come themselves". The rows of considered poetic works show the value of every minute of existence, of every living being, the uniqueness of every human life. Kindness, filling his verses, contributes to the enrichment of the spiritual universe. In the process of perception, there is a multiplication of the positive in opposition to aggression, which increasingly captures modern people, subject to the ideology of the consumer society. The research was carried out at the expense of the author of the article. Grants were not used.
\end{abstract}

Keywords: Poetry, War, Participant, Afghanistan, Ukraine, Former Soviet Union

\section{Introduction}

Modern conditions of the society development contribute to the fact that the channel of scientific thought goes toward researching military-patriotic creativeness. Since the end of the twentieth century, scientists have resorted to a conceptual re-evaluation of artistic, figurative and aesthetic values that were inherent in the past. Research is also a subject to such aspects that rarely became, or were not at all the subject of scientific research, which naturally leads to a significant expansion of the range of problems, issues actively developed by modern scientific thought. Different concepts and interpretations of various historical events sometimes provoke opposing reactions in society. The cultural aspect in this sense is a reflection of the development of social consciousness and the guiding force of the future. Creative contribution to the treasury of the culture of individuals requires special attention on the part of scientific thought. In our opinion, the verses of a participant of a war in
Afghanistan, who served as a soldier Alexander Ielagin are worthy of comprehensive study and wide application.

This work is a highlighting the original importance of the creativeness of the winner of many Festivals, the owner of the Silver Pen of Russia Prize, the poet, who passed the war in Afghanistan, Alexander Ielagin as a phenomenon of culture in several parts of its manifestations [1]. It should be noted such kind of research is becoming more relevant the deeper realization of a need for patriotic and spiritual upbringing. This article is the result of many years of work, visits to many international festivals of military-patriotic songs and poetry, poetic creative meetings, meetings with students (recorded on a Dictaphone). Personal example, the wealth of the inner world, transferred to the creative plane, attracts the attention of the author of this article to the talent of the unique personality of Alexander Ielagin.

The main thing in the work of Alexander Ielagin is the military- patriotic theme. The scientific novelty of this research in the context of a world science is the relevance of studying the topic of the Afghan war today, after the 
withdrawal of American troops from Afghanistan and the emotional experiences of American soldiers, who also turn to the poetry for expressing their experience, like our Ukrainian poet does. The problem of the war in Afghanistan is actual in such awful situation as an increasing the number of terrorist acts in the world. We can know it from the pages of the United States Institute of Peace [2]. Saad Khan (2017) in his work "The Afghanistan Problem, and a Solution", published by the Berggren Institute writes: "The US government has faced a difficult task in Afghanistan. The eight years of the Bush-Cheney Afghan policy have not borne fruit, and the Taliban are confidently moving forward. On the other hand, the US and NATO forces have entered the line of defense. August was the most deadly month for Americans after the invasion of Afghanistan in October 2001. Despite the presence of more than 100,000 members of the US and NATO forces, the question is what is being prepared in this forgotten country. There is an increasingly prevalent public sentiment that Afghanistan is becoming another Vietnam for the U.S."[3]. Thus, the tragedy of the war in all its manifestations became a pain for US soldiers, as well as for those people from the Former Soviet Union. They had to obey one's orders and they perished on the foreign land. And this is a great tragedy. Michael E. O'Hanlon also point on this problem in the article "America's Afghanistan problem: It's not just about sending more troops" [4].

Vanda Felbab-Brown is a senior fellow in the Center for 21 st Century Security and Intelligence in the Foreign Policy program at Brookings, the director of the Brookings project "Improving Global Drug Policy: Comparative Perspectives and UNGASS 2016" and co-director of another Brookings project, "Reconstituting Local Orders" known as an expert on international and internal conflicts and nontraditional security threats, including in surgency, organized crime, urban violence, and illicit economies. Her field work and research have covered, among others, Afghanistan, South Asia, Burma, Indonesia, the Andean region, Mexico, Morocco, Somalia, and eastern Africa. She writes: "The principal objective of U.S. policy in Afghanistan since the 9-11 attacks has been - and appropriately continues to be-to ensure that the country does not become a haven for virulent salafi (radical anti-Western jihadi) terrorist groups like al Qaeda. The premise underlying this policy subsequent to the toppling of the Taliban regime in 2001 is that if any part of the liberated territory once again comes under the control of salafi groups or a Taliban sympathetic to such groups, their capacity to increase the lethality and frequency of their terrorist attacks - including against U.S. assets-will increase since they will be able to use the safe-havens to plan and train for their operations and more easily escape retaliation by the United States and the international community" [5]. So, Afghanistan is a country full of unexpected things for people of European and American culture, for the mentality of civilization. This country has its own laws, cruel and incomprehensible, which are not spoken about at diplomatic levels, but soldiers returned from this war cannot forget everything they've seen.
Other literary scholars can turn their attention to the creativity of an American and British soldiers, those who returned from the war, like in our study.

The practical significance of the work is that its materials can be used by students of philological special ties who study the development of modern literature, as well as students of art departments as additional material on the history of art, students of historical, military faculties, postgraduate students and all those who are engaged in research the Afghan war. Separate fragment soft his work can be used in the process of studying the documentary genre in art and poetry, since the development of military-patriotic creativeness and techniques of its materialization are inextricably linked with the development of a culture of artistic perception and reflection of the environment.

\section{Methods}

The methodological basis of our work is the literary, philosophical ideas of such scientists as V. Kononenko [2], R. Gromjak [3], N. Khamitov [4], N. Sanotskaya [5], O. Galich [6], V. Nazaretz [6], Ye. Vasiliev [6], P. Gubernskii [7], V. Andruschenko [7], I. Shpachinsky [8], N. Krylova [4], V. Shejko [9], O. Gavryushenko [9], O. Kravchenko [9] and many others [28-32], which are aimed at revealing the regularity development of the artistic mentality, its relationship with the world's major art processes.

In this paper we use the methods proposed by modern cultural studies, the theory of literature, art, in particular, the method of structural analysis is used. For proving the author's assertion of this scientific article, it is resorted to the use of such methods as the study and analysis of scientific literature, literature of philosophical content. Methods of conversation, observation were also used. The experiment is the organization of creative meetings with young people and trips to festivals of military-patriotic creativity that took place in the period 2009-2017 in Ukraine and in the countries of the former Soviet Union, as well as film festivals where the works of Alexander Ielagin were presented. The final stage was the processing of results and summing up them in the form of the development of methodological recommendations in the edition of the author's scientific monograph "Cultural Aspect of the Creativeness of Alexander Ielagin".

\section{Literature Review}

According to the study of Mohammad I. "at the end of the 20th and beginning of the 21st century, Afghanistan faces serious problems of instability due to internal conflicts and wars, due to the internal power struggle between different groups. Sardar Daud took power of his cousin in 1971. Other groups supported by the USSR from time to time made various revolutions. In 1979, the Soviet Union introduced its troops into Afghanistan, and a war broke out between the Mujahedeen and the Soviet Army. This battle created destruction, destroyed infrastructure and made the country 
unstable [10]. Mohammad I. points out the reasons for the long wars in Afghanistan and does an accent that the war led to instability, hatred, inequality and destruction in Afghanistan. This war was imposed by the Afghan elite, and the credit comes from their wrong decisions. Before the war, Afghanistan was a prosperous country. A large number of tourists arrived in Afghanistan, which, in turn, provided a fairly large income to the national treasury. The main cause of instability was the ideological war between the two super powers of the USSR and the United States in the era of the Cold War. Both had their own interests in Afghanistan..."[10].

Another useful work was made by Neta C. Crawford from Boston University [11]. The scientist wrote in the report a summary the separate toll of war on civilians in Afghanistan. Neta C. Crawford described two kinds of war-related death and injury.

Mark Eggerman and Catherine Panter-Brick noted in their study "Suffering, hope and entrapment: Resilience and cultural values in Afghanistan" that in Afghanistan political and military conflicts have led to massive disruptions of livelihoods, education, and network of social support [12]. "Afghan families endure pervasive poverty, economic instability, and persistent violence. Since the fall of the Taliban regime in 2001, and in the context of an ongoing war, large scale reconstruction programs have raised expectations for socio-economic advancement, accentuated inequalities, and led to wide spread frustrations with persistent social injustice" [12].

The work "Crime and War in Afghanistan: Part 1: The Hobbesian Solution" by John Braithwaite and Ali Wardak shows us the period after the war with USSR. Article views Afghanistan less as a war, and more as a contest of criminalized justice systems. "The Taliban came to power because they were able to restore order to spaces terrorized by armed gangs and Mujahedeen factions. After the Taliban's 'defeat' in 2001, their resurgence was invited by the failure of state justice and security institutions. The Taliban returned with a parallel court system that most Afghans viewed as more effective and fairth an the state system. Polls suggest judges were perceived as among the most corrupt elements of a corrupt state. Police were widely perceived as thieves of ordinary people's property, not protectors of it. While the US diagnosis of anomie in Afghanistan up to 2009 was aptly Hobbesian, its remedy of supporting President Hamid Karzaiasa Leviathan was hardly apt. The West failed to as kin 2001 'What is working around here to provide people security?'. One answer to that question was jirga / shura. A more Jeffersonian rural republicanism that learnt from local traditions of dispute resolution defines a path not taken" [13].

Some useful information gives us the Official site of Global Policy: "Afghanistan, remote and mountainous, has seen many conflicts. The terrible civil war of more recent times began in 1979 as the Soviet Union intervened to prop up a friendly regime. For nearly a decade Islamic rebels, backed mainly by the United States and Saudi Arabia, fought the Soviet army. The CIA secretly funded and armed
Maktabal-Khadimat, established to recruit and train fighters from around the Arab world to battle the Russians. Osama Bin Laden was one of its top leaders. The rebels eventually forced a Soviet withdrawal in 1989. There followed a violent power struggle between the various Islamic militias, never unified, for control of the country. The Taliban, supported by Pakistan, won control of the capital, Kabul, and most of the country by 1996. On October 7, 2001, the United States launched military strikes against the Taliban regime in retaliation for the terrorist attacks on the World Trade Center, said to have been master minded by bin Laden from his base in Afghanistan. Shortly after the September 11 attacks, the US demanded the Taliban surrender Bin Laden to the appropriate authorities, but the Taliban rejected the ultimatum. US military intervention followed. At the UNsupported Bonn conference in December 2001, representatives from four Afghan factions agreed to establish a broad-based interim government. The US-backed Pashtun leader Hamid Karzai, exiled under the Taliban, was installed as Afghanistan's new interim president"[14].

Jeffrey Broun together with Thomas Johnson, a scientific professor and director of the Program for the Study of Culture and Conflict in the Naval Postgraduate School of the United States focused their attention on the poetry of the Taliban as a weapon in the article "Poetry as a Weapon of War in Afghanistan" [15]. Their point of view is fully supported by the author's one of this article, since the author believes that poetry, thanks to the rhythm, can induce people to act. The next actual direction in the philological sciences is the study of the peculiarities of female poetry in Afghanistan. Studies of Eliza Giswold [16], Bashir Sakhwaraz [17], Jaala A. Thibault [18] are devoted to the poetry of women in Afghanistan.

We consider the trail of war in the soul of a Soviet soldier, and this approach has become especially relevant today, after the returning of American and British soldiers from Afghanistan, who having experienced the hatred of the Taliban, their cruelty, began to write poetry, there by expressing their inner feelings. The poems of British soldiers also represent a valuable treasury of human experience and creativity. They are worthy of attention of scientists. Poems can be found, for example, on the special site [19]. The author of the article is convinced that the study of the creativity of individual poets, participants in military operations in Afghanistan is a novelty and interest in the context of world science.

\section{Results}

There is a special word in Ukrainian, that can be translated as Afghan. And its meaning is a soldier who was fighting in Afghanistan in the war 1979-1989 as member of the Soviet Army. Faced with the creativity of those who passed the war, we see that military-patriotic creativeness is a separate layer of the common culture of mankind. This is the subject of our study "Culturological Aspect of Creativity of AfghanWarriors" (Lebedeva N. A., 2009) [20]. Recently, there has 
been an extremely high figurative and intellectual level of artistic consciousness, its access to a wide arena of culture. Means of culture, such as, for example, cinema, poetry and music have always been some means for expressing ideological and ontological thought, foundations, canons, and also represented a form of retransmission of mental uniqueness, individuality and expression of psychological self-identification.

Military-patriotic creativity is a multi-faceted phenomenon with a rhetorical conceptual world and significant artistic and aesthetic features. One of these features is the manifested combination of several types of art in the work of individuals, which contributes to the education of young people in the best human traditions. The work of Alexander Ielagin is special, that's why it is necessary to reveal its uniqueness.

Such personalities as Alexander Ielagin are able to show young people by their own example, how to appreciate and respect life, the legacy of the past. Poetry unites and inspires people. With its help, mankind is given as a general way of knowing the world, as well as a way of mutual understanding, a common experience and a special language, which, in turn, expresses the most secrete motional experiences. That is why creativity of an individual poet can be placed in the context of the search for studies as a science, contemporary art, history and philosophy.

The purpose of the article is to describe the features of the poetry of a war actions' participant, the contemporary Ukrainian poet Alexander Ielagin and to acquaint Englishspeaking colleagues with military-patriotic creativeness in Ukraine. The object of this research is the formation of a unified system of knowledge about the poetry of A. Ielagin in the field of spiritual enlightenment. The subject of scientific research are verses, poetic texts of songs, with their typological links with historical and philosophical thought. The following tasks were set during the author's research:

1. To study current sources on Afghan wars problem.

2. Taking into account the current conditions in Ukraine to study all the poems of Alexander Ielagin, which are published in Ukraine.

3 . To visit poetry festivals.

4. To describe the results of studying literature and visiting festivals.

Alexander Ielagin kindly gave the author of the article his autobiography, which, in our opinion, should be quoted verbatim in this paper, since the most reliable facts are fixed in it. In addition to accuracy, this document contains a very strong emotional component that helps us better understand and feel the content of Alexander Elagin's poems. "I was born on June in the city of Karshi Uzbekistan, in the family of a serviceman. My grandfather took part in the RussiaTurkish war, had military awards, was wounded in battle. My father reserved as an officer, served in the Soviet Armed Forces for 29 years. He was a participant in the war actions in the United Arab Republic in 1967" [1], [21].

"In 1975 I entered the Chelyabinsk Higher Military Automobile Command School. In the summer of 1979, after graduating from the college, I arrived to serve in the Transcaucasia Military District of Tskhinvali as a deputy commander of a technical company, a separate battalion of helicopter regiment support. On the night of December 31, January 1 , our military unit was raised by alarm. We were read an order to relocate our unit to the Turkestan Military District for three months to conduct the military training. On the night of January 14, in the village of Termez, we were read out by the order of the Minister of Defense of the USSR about the dispatching of our military unit to the territory of Afghanistan in order to fulfill the international duty" [1], [21].

"For me, Afghanistan was a country with new impressions, its laws, struck poverty in which this people lived. In Afghanistan, we were soldiers and were obliged to carry out the order".

"How did I get used to the peaceful life after returning home? To be honest, Ican not accustomed to peaceful life even now, having served 21 years in combat units. The only thing that surprised me when I got home was that I haven't heard shoots, I had a sense of danger for more than a year" [21].

So, we pay attention on the poet's feelings, which served as the origin of the beautiful verse "The Smell of Spring" in its content and form: "In mid-May 1980, it was already very hot in Afghanistan. The air temperature rose to $50^{\circ} \mathrm{C}$. A crazy wind - the "Afghan" was a wall of sand and dust. I was staying in the hospital in Kabul for two weeks. It was always accompanied by the smell of sand, blood and medicine. We were wounded and injured, waiting for an ambulance to the territory of the Soviet Union. Our plane landed on a late night at a military air field in the Tashkent city. When the doors were opened, cool air blew into my face, which brought the aroma of grass, flowers-it was the smell of the Motherland, the smell of spring..." [22, p. 11]

Through a poetic form, Alexander Ielagin represents a picture that causes a real perception of the subjective world of the poet that is reproduced by the reader. Consequently, all his feelings are conveyed, deeply penetrating into the soul of the recipient:

В Кабуле весну я искал в медсанбате - Лишь морфий и кровь в умираюшем брате... И запах машин, что в дорогое горят. А раны в душе, как на теле, болят...

Но надо вернуться и дальше идти. Ведь что-то не сделал на том я пути... Губами касаюсь прекрасных волос, Что дыимат весной, тонким запахомроз.

(In Kabul, I was looking for spring in the medical battalion- / Only morphine and blood in a dying brother... / And the smell of cars that are burning on the road. / And wounds in the soul, as on the body, hurt... / But we must go back and go on./ After all, I did not do something on that way... / I touch your beautiful lips with beautiful hair, / What are breathed by spring, the delicate smell of roses) [the translation is made by the author of this article].

This feature of art in military-patriotic creativity can be considered in two ways: as a problem of the artist, the past war, its difference from other people, and as a problem of the 
perceiving public. The collection of poems, published in 2005, vividly illustrates our assumption. The emotional content of the book is best described by a member of the National Union of Writers of Ukraine, laureate of the Vladimir Sosyura International Prize of the Interregional Union of Writers of Ukraine, famous literary critic and a writer Lada Fedorovskaya: "Alexander Ielagin's book allows the reader to feel an experience of this double reality-because every death-carrying explosion, every shot to the back of a comrade responds with a sharp pain in the heart of the lyrical hero of the collection. Maybe, because the author and his main hero-narrator doesn't coincide so often spiritually and personally, as they say, one to one. Yes, that's right, because the pain permeating the trustful, confessional lines of $\mathrm{A}$. Ielagin is not only his personal state. Poems with utmost truthfulness convey the psychology of the whole generation of those of our fellow citizens who are now called "Afghans" $[22$, p. 6].

While reading the poems of Alexander, you involuntarily get in to that far-off world, with its uneasy laws, and, thus, the pain of the author and his brothers becomes the pain of the reader. And this is very important, because far from very poet's succeeds in penetrating deeply into the inner world of his reader, especially not having seen the horrors of war.

A unique, in our opinion, composition, spatio-temporal construction has a poem "Seryoga - my friend is looking and being silent..." [22, p. 10]. The reader is given by a visual picture, a poetic landscape, expressed by plans, like the compositional construction of paintings in arts, and the sound: "Гром. Ночь. дождь в окно стучит. Все замерло. Друг смотрит и молчит" (It's thundering. It's night. And the rain is knocking to my window. Everything is staying. The friend is looking and being silent) -passing into the subjective world of the author and the unfolding new landscape, a new terrible picture:

Саланг. Мы или меж гор. И перевал - Еще чуть-чуть, и впереди - привал. Я вспьшку вижу под машиной -под тобой. Подрыв. Тебя я сльшиу - ты живой!..

И вновь огонь. Чужая грязь и пыль. Нет -нет, не сон. Да, было... Это - быль. Бэка сработал. И машина в языках огня, Горело все: и ты, и плавилась броня...

(Salang Pass. We walked between the mountains. And the pass / A little more, and ahead - a halt. / I can see the flash under the car - under you. / Undermining. I hear you -you're alive!.. / And fire again. Someone else's dirt and dust. / No, no, not a dream. Yes, it was... It's a by gone. / Guns worked. And the machine in the tongues of fire, / Everything burned: you, and the armor melted...) [Translated by the author of the article]

The horror of the experience with a new force is pulled out and projected onto the objective world surrounding the author, and there is a mixture of space sand time, on the one hand - the end of the war, on the other -it lives within the human soul for 25 years and constantly reminds itself of physical pain:

Thunder. Lightning. And the rain is knocking again.

I will help. I'm near. It's early to die.
I regained consciousness in the medical battalion, my brother.

The end of the war: that fight ended...

Seryoga looks at me and says nothing.

Sereoga - the son in a crib peacefully sleeps.

Oh my God! As an awful headache and it hurts!

And the rain ruthlessly cries, and knocks. [22, p. 10], [Translated by the author of the article]

The planned construction, typical for painting, is vividly reflected in the poetry of Alexander Nikolayevich, for it is not without reason that he also has an artistic talent. Probably, such a special perception of the world makes his poems so "alive", palpable and penetrating. Turn to the poem "Night on the Salang Pass". At meetings with students, before reading the poem, Alexander Ielagin usually makes are mark describing the area itself - the Salang Pass. The Salang Pass is the lowest and most accessible place in the ridge of the Hindu Kush mountain range, which connects the northern and central parts of Afghanistan. Its height is about 4000 meters (Wikipedia gives us a number of $3.878 \mathrm{~m}$ ) [23]. Through it is a strategically important road. According to the meeting with students in Kherson (Ukraine) in October 4, 2016, we know if the column of cars goes down, then the temperature reaches 70 degrees of heat (in summer), and when you climb the pass itself, it's frost. The road "zigzag" rises, there were cases that cars fell into the cliff. The Mujahedeen, the "dushmans" (as soviet soldiers called them), who knew the peculiarities of the pass, tried to set fire to the first and last vehicles in a column carrying fuel or foodstuffs, and then fired the whole column. But, despite all this horror there is a special beauty of Salang: sunrises and sunsets, a song of a mullah, rein forced by a mountain echo, and stars. "The stars are so bright and large that it seems that if you reach out, you can touch them. Usually, when we were travelling, we did not have time to cross this pass by one walk, because the cars climbed an arrow road, then descended, there were roadblocks, there were such "pockets" at roadblocks where we rested, the equipment became organized. All the time it was necessary to be ready for everything..." [a recording of a meeting with high school students dated 04.10 .2016 , made by the author of the article on a Dictaphone]

In the poetic work "Night on Salang Pass" [22, p. 13], we again observe special spatio-temporal relations. The author surprisingly stops the flow of time, thereby enabling the reader to plunge in to the "here and now" state in the atmosphere of silence of the interruption of military operations.

Further in the poem we find the pictures of the future in relation to the moment of the poet's stay in the war, while at the same time realizing that this is already the past. The combination of incompatible concepts makes the image of war special.

The eternity and uniqueness of poetry is sung in a remarkable poem dedicated to Alexander Pushkin "You wrote about the wild mountains beautifully" [22, p. 64]. The composition of this verse is interesting: in the beginning 
there is a harmony of A. Pushkin, inspired by its author romance, then there are terrible pictures of the Afghan war, seen by the modern poet, and the climax is in the wards: "Burn us in cars, brother, with you" [22, p. 64].

The military theme is fundamental in the poems of Alexander Ielagin. This is something that does not give him peace, what he considers his holy duty. Love, women's destinies, children's dreams - all this is, but in the context of military themes. Thus, in the poem "The Widow" [22, p. 18] the poet tells about the fate of an officer's wife. Her husband died in Afghanistan. This is not just a story, it has a lot of soulfulness that any reader touches for the living. Love, the victorious life, wounded by grief still continues to live and will remain immortal, because the children will carry it.

The main idea of the work is also supported by compositional construction. In the beginning-a waltz on the dance floor, the ending - the daughter's dance with the officer. Continuity of being is revealed by the author of the poem as best as possible.

His heart felt lyrics are colored with the blood of the Afghan war, and the continuation of the theme of the feminine feat is found in the poem "I pick Meadow Flowers in Spring..." [22, p. 33].

The heavy military theme reveals to the reader the tragedy of the author's soul and experiences. There is a feeling of pessimism, however, we can find another facet of Ielagin's poetry - children's poems, which represent a completely opposite direction of the poet's creativeness. The book "Teddy-bear" [24] was published in 2011. Poems for children are characterized by ease and immediacy. Reading them, it is difficult to assume that they are written by such a serious and experienced man. Verses for children are remembered very quickly, thanks to the ease of their form and simplicity of a plot. They are written from the child's point of view.

Each poem is a story, having its own unique plot, dynamic line. For example, getting acquainted with the poem "Two black insects" [24, p. 9], the reader learns about a little boy who did very important things: he woke up, played, ate, and went to bed again. Comparison of child's eyes with insects gives an idea of their color and shape, filling with tenderness and a smile. By the way, children like these verse very much.

In 2014, two regular collections of poems by A. Ielagin were published. "Why Do I Write about the War..." [25] and "The Beetle" [26].

"Why Do I Write about the War..."-this is the name of a book that combine military-patriotic and lyrical themes. Lyrically, the author of the collection tried to remove the tension that arises in the process of reading poems that touches upon the themes of military operations. The horror that arises before the eyes must be necessarily mitigated by the lyrics, because psychologically a reader cannot understand and cannot finish reading the book to the end. For example, "We are not afraid of teaching children..." [25, p. 48] tells about education in Afghanistan, when two teachers taught children and were killed. They were thrown into the fire. And their pupils were punished brutally - on the right handles, their fingers were chopped off... Such events, horrible and bloody, are described in verse "The death camp in their life was..." [25, p. 74], "War will knock on your house" [25, p. 79], "I am burning in the fire myself..." [25, p. 81] and many others. But each of these poems is unique, and they are read in one breath because after the "battle" there is a lyricism dedicated to the wife, mother, father, children. The compositional construction of the book takes the reader to Afghanistan, where terrible pictures of the battle are seen before one's eyes, and when he closed his eyes - the faces of loved ones has been seen. This gives the impression that the book has a soul. For example, "I'm sick, my dear, by you" [25, p. 77]:

I'm sick, by you my dear,

You are my gift of Fate.

I was not on my knees-

But bent before you down.

Do not scold, well, pity me,

Forgive the fire of my soul.

Let be me ugly, a little rude.

I'm crazy with lips of your.

In the context of this study, we should also mention the song, which premiere was on February 15, 2007 in the Kherson Regional Youth Palace, and the video was published on the Internet only in 2010 [27]. The words of the song were first printed in the collection of 2014 "Why do I write about the war...". This is" A Letter to Mujahidin" ("I want my father to return home...") [25, p. 89], presented by a little girl Nastya, sounded in her performance for the first time [21]. Music was written by children's composer, the teacher and a head of the vocal studio Andrei Beletsky for Anastasia Lebedeva. A plot of the song is simple enough: the girl is writing a letter... This letter is addressed not only to her father, but also to the enemy. The peculiarity of the song is a high degree of sincerity. The child asks the enemy to let his father go home to her:

I will write a letter to uncle dushman:

"Do not shoot my daddy!" - I'll ask him.

My dad is good and handsome one!

I want him to return home... to us with my mother

The peaceful life in which the child is, does not bring any joy to the girl, because of father is not next to her. The little girl comes to a railway station everyday with the only hope in her heart - the train from Tashkent will arrive and bring her father. Even all the efforts of a mother to distract the child with fairy tales prove to be futile. The pure child's heart hopes that the enemy would show mercy and let her daddy go home just because she, a little daughter writes him a letter. The relevance of this song will remain for a long time, because of new war stake away the parents from children.

Many poems are dedicated to the poet's friends: "I was served in Tskhinval" in honor of Igor Gorbatov, "I'm in the PPS" and "You know I do not drink vodka" for Viktor Sarayev, "You knew you could win!" for Viktor Sychev, "Talk to me" to Igor Kramarenko, "All his life was checked by fate" to Viktor Arinich, "In Afghanistan you are a company..." in honor to Oleg Karpenko.

With his creativeness Alexander Ielagin tries to shout to 
people: "War is grief! Everything must be solved peacefully!" He was there, he knows it. He knocks on the hearts of the young.

A sympathetic kind person shows himself in another work that does not concern the war topic at all - it is a collection of children's poems "The Beetle" [26]. This is a little book, illustrated by Anatoly Bukharov. Bright illustrations represent a background on which poems are printed. This verse tells about everyday life of a little boy, for whom every minute of his life is a big and unknown miracle. Conditionally the book can be divided on the themes: dayhouse, walk, zoo, evening -preparation for a sleep. Every minute of life of little Sasha carries with him some interesting event, or a journey.

Children's works of Alexander Nikolayevich teach kids to love. An example of this may be seen in the poetry "Oh, toy are sad" [26, p. 43]. The problem of all parents is that when buying an expensive toy becomes a cause of sadness as the child does not know how to take care of this thing. The poem teaches children to cherish toys, because the poet animates things, giving them a special meaning.

In poem "The Butterfly" [26, p. 26] the ecological theme of the upbringing children is traced. The theme of goodness, love of the surrounding world fills this poetic work. Little Sasha was running around, catching a butterfly. He really wanted to catch her, to play the way he played with toys. But to catch the butterfly was not possible because the boy fell down.

The lines of the considered poetic works show the value of every minute of existence, of every living being, the uniqueness of every human life. The projection in the poems of the inner kindness and love of the poet, the materialization of thought in verse form finds a response from the reader and cause a reciprocal impulse of love, mercy, desire to help. Kindness, filling his verses, contributes to the enrichment of the spiritual universe.

\section{Discussions}

As it's known, poetry is a word art. The most sacred of human feelings have long been expressed by people in verses and poems, but not every person is endowed with talent of writing poetry. Since poetry is one of the forms of art, we come to the understanding that its essence, the essence of poetry, as well as of art, lies in the fact that its foundations are the ultimate foundations -the vitally significant human experiences that stand out from a number of others with its special meaning. They do not represent characteristic forms of cognition, but it can be performed as a function of experience on the principle "I know - I experienced it". The quality of the internal and philosophical content A. Ielagin's poetry was highly appreciated at the International and AllUkrainian Poetry Festivals such as All-Ukrainian Festival of Military-Patriotic Creativity "Obereg" in the nomination "The Best Writer" (Ukraine, Kherson); the poet was admitted to the International Commonwealth of Writers' Unions, the Interregional Union of Writers of Ukraine. The title of
Laureate in the nomination "Poetry" of the International festival of military-patriotic songs and poetry "Gun and Guitar" (r. p. Rudnya, Volgograd region, Russia), International festival of military-patriotic songs and poetry "Afghanistan hurts in my soul" (Belarus). He has the title "Laureate" in the International Literary Prize "Silver Feather of Russia". Alexander Ielagin is also a member of the AllUkrainian Creative Union "The Congress of Writers". All the documents (even more than poetry) may be found in the official site of the poet which in references has number one.

\section{Conclusions}

As a result of studying philosophical and literary sources, scientific articles on the history of the Afghan wars, modern English studies, the presence and documentation of the high recognition of A. Ielagin at festivals of military themes in Ukraine and countries of the former Soviet Union, preparing creative meetings of the poet with students and school children in Kherson (Ukraine), a conclusion is made about the relevance of studying the verses of participant of a war in Afghanistan both in the context of Ukraine's scientific thought and world science, because the participants of the war from English-speaking countries also write poems that reflect their emotional experiences and feelings, the pain of losing friends and longing for their home, just as the Ukrainian poet Alexander Ielagin writes about it. In Ielagin's poetry, the author's personal memories are passed on to the reader.

The lines of the considered poetic works show the value of every minute of existence, of every living being, the uniqueness of every human life. The projection in the poems of the inner kindness and love of the poet, the materialization of thought in verse form finds a response from the reader and cause a reciprocal impulse of love, mercy, desire to help. Kindness, filling his verses, contributes to the enrichment of the spiritual universe.

\section{Acknowledgements}

To the Kherson regional organization of veterans of war in Afghanistan and personally to its head - Vladimir Stolyar, Alexander Ielagin, Andrei Beletsky for the creation of a beautiful song.

\section{References}

[1] The official site of Alexander Ielagin (2010), available at: http://www.a-elagin.org (Accessed 25 October 2017)

[2] The Current Situation in Afghanistan. AUSIP Fact Sheet (2017) Friday, January 13, available at: https://www.usip.org/publications/2017/01/current-situationafghanistan (Accessed 30.10.2017)

[3] Saad Khan (2017) The Afghanistan Problem, and a Solution, published by the Berggren Institute, available at: https://www.huffingtonpost.com/saad-khan/the-afghanistanproblem-a_b_275407.html (Accessed 30.10.2017) 
[4] Michael E. O'Hanlon (2017) America's Afghanistan problem: It's not just about sending more troops, available at: https://www.brookings.edu/blog/order-from-

chaos/2017/05/25/americas-afghanistan-problem-its-not-justabout-sending-more-troops/ (Accessed 30.10.2017)

[5] Vanda Felbab-Brown (2017) Afghanistan's terrorism resurgence: Al-Qaida, ISIS, and beyond, available at: https://www.brookings.edu/testimonies/afghanistansterrorism-resurgence-al-qaida-isis-and-beyond/ (Accessed 28.10.2017)

[6] Kononenko B. (2017) Bol`shoj tolkovыj slovar` po kul'turology'y'[Great Dictionary of Cultural Studies], available at: URL:

http://dic.academic.ru/dic.nsf/enc culture/2443/\%D0\%A4\%D $0 \% \mathrm{~B} 0 \% \mathrm{D} 1 \% 88 \% \mathrm{D} 0 \% \mathrm{~B} 8 \% \mathrm{D} 0 \% \overline{\mathrm{B}} 7 \% \mathrm{D} 0 \% \mathrm{BC}$ (Accessed 20.10.2017)

[7] Literaturoznavchy`j slovny`k-dovidny`k / Red.: R. T. rom'yak (2007) [Literary Dictionary-Reference / Editor R. T. Gromyak], 2 nd ed, Academy, Kyev, Ukraine.

[8] Khamitov N. V., Kry`lova S. A. Filosofs'ky`j slovny’k Lyudy`na i svit (2007), [Philosophic Dictionary. Human and World.], KNT, Kyev, Ukraine.

[9] Sanotskaya N. Ya. (2011), "The phenomenon of creativity: the transformation of semantic dimensions in the European historical and philosophical tradition", PhD Thesis, History of Philosophy, National Lviv University, Ukraine.

[10] Galy`ch O. A., Nazarecz` V. M., Vasy`l’yev Ye. M. (2005) Teoriya literatury' [Theory of literature], 2nd ed, Lybid, Kyev, Ukraine.

[11] Gubers`ky`j L. V., Gubers`ky`j L. V., Andrushhenko V. P. (2011) Filosofiya [Philosophy], Vikar, Kyev, Ukraine.

[12] Shpachinskii I. L. (2006), "Creative potential of the person and its realization in the conditions of transformation of society", Ph.D. Thesis, Social philosophy and philosophy of history, Odessa National University, Odessa, Ukraine. Shejko V. M., Gavryushenko O. A., Kravchenko O. V. (2007), Istoriya svitovoyi kul'tury' [History of world culture], Kondor, Kyev, Ukraine.

[13] Mohammad I. Instability in Afghanistan: Implications for Pakistan Journal of Political Sciences \& Public Affairs, available at: https://www.omicsonline.org/openaccess/instability-in-afghanistan-implications-for-pakistan2332-0761-1000213.php?aid $=($ Accessed 18.10.2017)

[14] Neta C. Crawford. War-reared Death, Injury and Displacement in Afghanistan and Pakistan 2001-2014 available at:

http://watson.brown.edu/costsofwar/files/cow/imce/papers/ 2015/War\%20Related\%20Casualties\%20Afghanistan\%20a nd\%20Pakistan\%202001-2014\%20FIN.pdf (Accessed 20.10.2017)

[15] Mark Eggerman, Catherine Panter-Brick (2010), Suffering, hope and entrapment: Resilience and cultural values in Afghanistan, available at: https://www.ncbi.nlm.nih.gov/pmc/articles/PMC3125115/doi: 10.1016/j.socscimed.2010.03.023 (Accessed 20.10.2017)

[16] John Braithwaite, Ali Wardak "Crime and War in Afghanistan: Part1: The Hobbesian Solution "The British Journal of Criminology, Volume 53, Issue 2, 1 March 2013, Pages179196, available at: https://doi.org/10.1093/bjc/azs065
https://academic.oup.com/bjc/article/53/2/179/416214/Crimeand-War-in-AfghanistanPart-I-The-Hobbesian (Accessed 23.10.2017)

[17] The official site Global Policy Forum "US Military Expansion and Intervention in Afghanistan" available at: https://www.globalpolicy.org/empire/26365-us-militaryexpansion-and-intervention-in-afghanistan.html (Accessed 27.10.2017)

[18] Jeffrey Broun, Thomas Johnson (2011) "Poetry as a Weapon of War in Afghanistan", available at: www.pbs.org/newshour/arts/taliban-poetry (Accessed 23.10.2017)

[19] Eliza Giswold (2012) "The Poetry of Afghanistan's Women, available at: http://pulitzercenter.org/reporting/poetryafghanistans-women (Accessed 24.10.2017)

[20] Bashir Sakhwaraz (2014) The Erotic and Revolutionary Poetry of Afghanistan, available at: https://www.englishpen.org/pen-atlas/the-erotic-andrevolutionary-poetry-of-afghanistan/(Accessed 25.10.2017)

[21] Jaala A. Thibault Afghans Build Peace, One Stanzaata Time, available at: https://atwar.blogs.nytimes.com/2012/02/15/afghans-buildpeace-one-stanza-at-a-time/ (Accessed 26.10.2017)

[22] The War Poetry Web Site, available at: http://www.warpoetry.co.uk/Afghanistan\%20War\%20Poetry.h tml. (Accessed 27.10.2017)

[23] Lebyedyeva N. A. (2009) Kul'turology`chesky`j aspekt tvorchestva voy'nov-afgancev [Culturological Aspect of Creativeness of Afghan Warriors], Kherson, Ukraine.

[24] Lebiedieva N. A. (2017) Kul `turology`chesky`j aspekt tvorchestva Aleksandra Elagy'na [Culturological Aspect of Creativeness of Alexander Ielagin], Izd. ANS "Sibak", Novosyobyorsk, Russia, available at: https://sibac.info/books/social/70285 (Accessed 28.10.2017)

[25] Ielagn A. N. (2005) Afganecz ya, y`bol tvoyu pojmu [I am an "Afghan", and I understand your pain], Star, Ukraine.

[26] Salang pereval [Salang Pass] available at: URL: https://ru.wikipedia.org/wiki/Саланг (Accessed 21.10.2017)

[27] Ielagn A. N. (2011) Medvezhonok [Teddy-bear], Kherson, Ukraine.

[28] Ielagn A. N. (2014) Zachem py`shu ya o vojne... [Why do I write about the war...], Kherson, Ukraine.

[29] Ielagn A. N. (2014) Zhuchok (sty`xy` dlya detej) [Beetle (poems for children)], Kherson, Ukraine.

[30] "A Letter to Mujahidin" ("I want my father to return home...") available at: https://www.youtube.com/watch? $\mathrm{v}=\mathrm{sx} 3 \mathrm{rFFfAw} 7 \mathrm{~s}$ (Accessed 28.10.2017)

[31] Literatura v konteksti kul'tury': zb. nauk. pr. (2006) [Literature in the context of culture: Conference Proceedings of the International Philological Conference], Vol. 16., Dnipropetrovsk National University, Ukraine.

[32] New Philosophical Encyclopedia of the Institute of Philosophy of the Russian Academy of Sciences (2010), 2 nd ed, available at: https://iphlib.ru/greenstone3/library/collection/newphilenc/pag e/about (Accessed 18.10.2017) 
[33] Pochemu nashy' vojsk aokazaly`s' v Afgany`stane?//V pry'cele (2008), [Why did our troops find themselves in Afghanistan?] issue by the 11-12-th of December 2008, Kherson, Ukraine.

[34] Lebedeva N. A. Orthodox movie in the context of counterweight to aggression as «analternative to evil» $/ / \ll$ Humanities and Social Sciences in Europe: Achievements and Perspectives». Proceedings of the 5 th International symposium (September 15, 2014). «East West» Association for Advanced Studies and Higher Education GmbH. Vienna. 2014.- P. 15-21.

[35] Lebyedyeva N. A. Alexander Ielagin's Documentary Films in Culturological Aspect // European Science and Technology [Text]: materials of the III international research and practice conference, Vol. II, Munich, October 30th-31st, 2012 / publishing office Vela Vertag Wardkraiburg - Munich Germany - P. 733-737. 